\title{
Characterization of the Production and Dissemination Systems of Nile Tilapia in Some Coastal Communities in Ghana
}

\author{
K. K. Mireku ${ }^{1}$, D. Kassam ${ }^{1}$, W. Changadeya ${ }^{2}$ \& F. Y. K. Attipoe ${ }^{3}$ \\ ${ }^{1}$ Department of Aquaculture \& Fisheries, Lilongwe University of Agriculture and Natural Resources (LUANAR), \\ P.O. Box 219, Lilongwe, Malawi \\ ${ }^{2}$ Molecular Biology and Ecology Research Unit (MBERU) DNA Laboratory Chancellor College, University of \\ Malawi, P.O BOX 280, Zomba, Malawi \\ ${ }^{3}$ Aquaculture Research and Development Center, Water Research Institute, P.O.BOX AB139 Akosombo, Ghana \\ Correspondence: Kwadwo Kesse Mireku, Department of Aquaculture \& Fisheries, Lilongwe University of \\ Agriculture and Natural Resources (LUANAR), P.O. Box 219, Lilongwe, Malawi. E-mail: kmireku@ucc.edu.gh
}

Received: June 28, 2017 Accepted: August 18, 2017 Online Published: October 24, 2017

doi:10.5539/sar.v7n1p14 URL: https://doi.org/10.5539/sar.v7n1p14

\begin{abstract}
Aquaculture development has been identified as a key process to meeting the demand for cheap and readily available source of protein. The resultant has been the springing up of cages along the Volta Lake with most farmers producing Nile tilapia. However, the sector faces an array of challenges which needs urgent attention. A study was undertaken to ascertain the production systems and dissemination channel of Nile tilapia among farmers along selected coastal regions in Ghana. A survey of 190 farmers representing the fish farming community in the area was used -these comprised 187 males and 3 females. Pond culture and cage culture were the most common holding facilities used constituting $58.8 \%$ and $28.9 \%$ respectively. The production of all-male tilapia was popular among farmers and constituted $66.8 \%$ of production, while the production of mixed sex tilapia formed $25.8 \%$. The study revealed that the high prices of fish feed and lack of access to finance were the top ranking financial challenge facing fish farmers in the area corresponding to $73.2 \%$ and $51.1 \%$ of the response respectively. Other factors such as distance to hatchery and price of fingerling was a significant factor affecting the choice of source of fingerling for stocking $(\mathrm{P}<0.05)$ for farmers who used dugout ponds. There was no clearly laid down protocol for dissemination the tilapia. Farmers (16\%) who undertook dissemination directly supplied fingerlings and broodstock to other farmers. Investment of capital into tilapia production can improve productivity and profitability.
\end{abstract}

Keywords: Oreochromis niloticus, Akosombo strain, socio-economics, culture systems

\section{Introduction}

Aquaculture and fisheries plays an important role in contributing to the protein nutrition in Ghana. The annual demand of fish exceeds $1,000,000 \mathrm{mt}$, whiles production is about 440,000 , leaving a deficit of $600,000 \mathrm{mt}$ (GNA, 2017). The role of aquaculture in meeting this deficit has become more pressing than ever. With a current annual aquaculture production of more than 50,000mt, the production is predicted to increase to over 100,000 metric tonnes by the end of 2017 (GNA, 2017). The sector employs 5,000 directly and 150,000 indirectly through the aquaculture market value chain (FAO, 2016). In 2012, the country ranked as the fourth food fish aquaculture producer in Africa, after Egypt, Nigeria and Uganda (FAO, 2014). However, with an ever-increasing human population, improved economic situation in some sectors, and greater awareness of the health aspects of fish, the demand of fish is predicted to increase (Ponzoni, 2006).

There are approximately 5000 fish farmers operating some 19000 fish ponds and cages in Ghana (FAO, 2016). Few farmers undertake pen culture and atidja/acadja culture; whilst mariculture is virtually non-existent in Ghana. Nunoo, Asamoah and Osei-Asare (2014) noted that both pond and pen aquaculture are profitable venture which needs to be explored. The latter also noted that that large-scale operations were more profitable and viable than small scale operations. The eastern corridor is the most productive sector contributing more than $80 \%$ of the total production. This area of the country is characterized by presence of the Volta Lake and Volta River which provide a conducive opportunity for cages culture. These cages are generally stocked to capacity and produce 
more fish per unit area compared to pond culture. Although Wijkstrom and MacPherson (1990) noted that aquaculture had the potential to alleviate poverty among the rural poor, a survey conducted in 2007 indicated that the rate of abandonment of pond was increasing (Asmah, 2008). The reasons attributed to this finding were lack of readily available tilapia fingerlings and the lack of readily available, standardized and affordable pelleted fish feed. However, with the growing demand for fish, there is a good and readily available market for tilapia produced, making the species the most preferred species in aquaculture (Nunoo, Asamoah \& Osei-Asare, 2014; Aseidu, Failler \& Beyens, 2016).

Nile tilapia (Oreochromis niloticus) is the mainstay of the aquaculture industry contributing more than $90 \%$ of the total production. Their ease of propagation, tolerance to handling, fast growth, as well as tolerance to a wide range of environmental conditions have been an important factor which has led to their increased culture. Oreochromis niloticus is a microscopic herbivorous feeder, subsisting mainly on phytoplankton, periphyton as well as fresh and decaying plant material (Moriera, 2002; Oteino, Kitaka \& Njiru, 2014). The species thrive in freshwater, and can be cultured with little or no supplementary feeding. Where feed is provided, small-scale rural pond farmers use wheat bran, maize bran, rice bran and brans of other cereals, which are readily available on the local market. In addition, other supplementary feeds which are used in aquaculture include agricultural wastes such as cocoyam leaves, agricultural-industrial byproducts such as local brewery waste, and household food waste (FAO, 2016). Tilapias perform well under different culture systems and have been produced under varying management strategies. This has made the culture of Nile tilapia one of the easiest and profitable ventures to exploit. However, the slow growth rate and their ability to stunt has been a major challenge to the industry. Given the importance of the Nile tilapia to aquaculture, the development of an improved strain has been carried out.

The most popular and well documented strain of tilapia in Ghana is the Akosombo strain. This strain was developed by the CSIR-Water Research Institute by a $4 \times 4$ diallel cross of three populations of $O$. niloticus, collected from three different agro-ecological zones within the Volta system in Ghana and a farmed strain from a local producer (Attipoe \& Abban, 2004; Attipoe, 2006). Although the strain grows about $30 \%$ faster than wild unimproved strains and has the potential to boost aquaculture in the country, the impact of this strain is yet to be felt due to the use of wild populations which have not undergone any genetic improvement programme. However, there is the need to identify and document other strains of Nile tilapia used by farmers and the factors that influence their choice of strain.

The intervention of government to support the aquaculture sector through the provision of fingerlings/Tilapia Breeding Programme, shrimp production, Nucleus-Outgrower Fish Farmers Scheme, Fish Feed Production and an Inland Fisheries Resource Management (GoG, 2017) can be achieved if the challenges facing the sector is addressed. The important role aquaculture plays in protein nutrition and enhancement of livelihood has brought to the fore the need to identify some of the important parameters which characterize aquaculture production in the country. However, given that there are limited hatcheries in the country, there is the need to identify the pathways for dissemination of fish. The research was set at identifying socio-economic factors that influences the breeding and the dissemination pathways used in Nile tilapia culture with special emphasis on the southern sector of the country. This will provide information necessary to advice management and bring to the fore some challenges that mitigate against the growth of the aquaculture industry.

\section{Materials and Methods}

Ghana has a coastline of $550 \mathrm{~km}$ which spans four different regions. The regions selected for the survey were Central, Greater Accra, Eastern and Volta regions. These regions contribute more than $80 \%$ of the total aquaculture production in the country (MOFAD, 2013, 2014). The Central and Greater Accra Regions are predominantly characterized by pond culture whereas the Eastern and Volta regions have more cages due to the presence of the Volta Lake / River. There are about 300000 individuals who directly depend on Lake Volta for their livelihood, of which 80000 are fishers and the rest are fish processors and traders (IDAF-Yeji Terminal Report, 1993; Bene \& Rusell, 2007; BoG, 2008).

A cross-sectional survey designed was employed to target individual fish farmers as well as officials of aquaculture departments. Sample size was determined using the formula derived by Kothari (2004). Within the regions, a stratified random sampling technique was used in the selection of respondents. Socio-economic data was collected through a structured questionnaire for the survey. All questionnaires were administered through face-to-face interviews by the researcher and research assistants. Data from questionnaires were coded and recorded into the spreadsheets of the Statistical Package for Social Sciences (SPSS vr 20) for statistical analysis. Socio-economic data analysis involved the use of descriptive statistics (means, modes, standard deviations, 
variance, percentages, and frequencies) whereas inferential statistics involved the use of correlation and chi square. A multinomial logistic regression model was developed to ascertain the relationship between predictor variables and the type of aquaculture facility used and source of fingerling/broodstock whereas a binomial logistic regression model was used to test the relationship between predictor variables and the possibility of disseminating tilapia. All statistics were tested at the probability level of $\mathrm{p} \leq 0.05$.

\section{Results}

A total of 190 respondents which included 3 females and 187 males were obtained from the survey. The age of the farmers ranged between 20 and 79 years, with a mean age within the 40-49 year range (Table 1). The level of education of the respondents indicated that $30.5 \%$ had JHS education, $45.3 \%$ had senior secondary education, whilst $17.9 \%$ had tertiary education. More than $90 \%$ were Christians, whilst the rest belong to either traditional, Islam and other religions. Married persons represented $83 \%$ whilst $11 \%$ were never married. There were $50.6 \%$ of the respondents who had been in aquaculture within the last three years whilst the remaining had been in aquaculture for more than 4years. In terms of persons been employed on the farm, 77\% employed 1-3 person whiles the remaining employed more than 4 persons; however, a few (3) farms employed more than 50 individuals. 
Table 1. Descriptive statistics of demographic characteristics of the respondents

\begin{tabular}{|c|c|c|}
\hline Parameter & Frequency & Percentage \\
\hline \multicolumn{3}{|l|}{$\operatorname{Sex}$} \\
\hline Male & 187 & 98.4 \\
\hline Female & 3 & 1.6 \\
\hline \multicolumn{3}{|l|}{ Age } \\
\hline $20-29$ & 18 & 9.5 \\
\hline $30-39$ & 35 & 18.4 \\
\hline $40-49$ & 69 & 36.3 \\
\hline $50-59$ & 53 & 27.9 \\
\hline$>=60$ & 15 & 7.9 \\
\hline \multicolumn{3}{|l|}{ Level of Education } \\
\hline No education & 2 & 1.1 \\
\hline Primary & 10 & 5.3 \\
\hline Junior High School & 58 & 30.5 \\
\hline Senior High School & 86 & 45.3 \\
\hline Tertiary & 34 & 17.9 \\
\hline \multicolumn{3}{|l|}{ Religion } \\
\hline Christian & 178 & 93.6 \\
\hline Traditional & 6 & 3.2 \\
\hline Other & 6 & 3.2 \\
\hline \multicolumn{3}{|l|}{ Ethnicity } \\
\hline Akan & 89 & 46.8 \\
\hline Ewe & 46 & 24.2 \\
\hline Dangme & 46 & 24.2 \\
\hline Others & 9 & 4.8 \\
\hline \multicolumn{3}{|l|}{ Occupation } \\
\hline Aquaculture & 49 & 25.8 \\
\hline Fisherman & 10 & 5.3 \\
\hline Farmers & 56 & 29.5 \\
\hline Teachers & 12 & 6.3 \\
\hline Formal Business & 24 & 12.6 \\
\hline Informal Business & 39 & 20.5 \\
\hline \multicolumn{3}{|l|}{ Marital Status } \\
\hline Single & 31 & 16.3 \\
\hline Married & 159 & 83.7 \\
\hline \multicolumn{3}{|l|}{ Number of children } \\
\hline No child & 19 & 10.0 \\
\hline $1-3$ & 76 & 40.0 \\
\hline $4-6$ & 86 & 45.3 \\
\hline$>7$ & 9 & 4.7 \\
\hline \multicolumn{3}{|l|}{ Number of Employees } \\
\hline $1-3$ & 145 & 76.3 \\
\hline $4-6$ & 27 & 14.2 \\
\hline$>7$ & 18 & 9.5 \\
\hline \multicolumn{3}{|l|}{ Source of funding } \\
\hline Self & 112 & 58.9 \\
\hline Family Support & 50 & 26.3 \\
\hline Bank Loan & 17 & 8.9 \\
\hline Joint partnership & 9 & 4.7 \\
\hline Government & 2 & 1.1 \\
\hline
\end{tabular}

Source and choice of fingerlings for Fish Farming

The respondents got their fingerlings from private hatcheries $(40.5 \%)$, governmental outlets $(35.8 \%)$, other farmers $(12.6 \%)$, self-propagation on their farm $(9.5 \%)$ and through collection from rivers (1.9\%) (Table 2). 
Famers obtained their fingerlings and broodstocks from farms in different parts of the country including Prestea (in the Western Region), MoFAD-Kumasi (in the Ashanti Region), Okyereko, Ekumfi-Esuohyia, Mankessim, Adjumako, Kasoa (in the Central Region), MoFAD-Ashiaman (in the Great Accra region), Akosombo, Akuse, Asutsare, Senchi, Sedorn, Dodi (in the Eastern region) and Fante - Akura (in the Volta Region). A reasonable proportion of the farmers (36.9\%) used the Akosombo strain whilst the remaining farmers used other strains of Nile tilapia. The Akosombo strain was obtained from ARDEC -Akosombo, Ashiaman, and Okyereko. The predominant culture system that was practiced was all male-tilapia $(66.7 \%)$

Price of $2 \mathrm{~g}$ fingerlings ranged between 0.14 Cedis and 0.22 Cedis $(1 \mathrm{USD}=4.31 \mathrm{GHC})$, with a mean price of 0.146 Cedis; however, farmers who got their fingerlings from other farmers had it for free or paid not more than 0.10 Cedis (Fig.1). There was a significantly high probability of a farmer undertaking self-propagation of broodstock and fingerling on farm to use multiple holding facilities (pond, tank and cage) as compared to the others $(\mathrm{P}<0.05)$. The respondents who used dugout ponds also noted that means of delivery of the fingerling as well the distance to the hatchery also influenced choice of fingerling; however same could not be said for respondents who used other facilities. Social status including level of education, age, type of occupation as well as source of income, did not affect the choice of fingerling for production $(\mathrm{P}>0.05)$.

Approximately $60 \%$ were self-funding their enterprise, $26.7 \%$ had some family support whilst $9 \%$ used bank loans. Partnership comprising two to five persons constituted $4.7 \%$, and government supported ventures were the least prevalent $(1.1 \%)$. Dugout ponds was the most dominant $(58.8 \%)$ holding facility used for aquaculture. This was followed by cages $(28.9 \%)$ whilst concrete tanks only were the least common facility used. All-male tilapia production was the most dominant culture method been used (66.8\%) whilst fewer farmers ventured into the production of broodstock (25.8\%). The remaining farmers undertook polyculture of tilapia with African catfish (Clarias gariepinus). Among the farmers who produced fingerlings, most of them (73.9\%) generally raised their fingerlings with the aim of stocking their own cages and sold a relatively smaller portion to other customers. Stocking density for pond culture ranged between 5-20 fish per square meter, whilst farmers who were into cages was between 200- 300 fish per square meter. Broodstock were kept in hapas of varying dimensions and used for production of fingerlings.

Table 2. Culture system and source of fingerlings of respondents

\begin{tabular}{lll}
\hline Parameter & Number & Percentage \\
\hline Source of fingerling & 3 & \\
Wild & 3 & 1.6 \\
Other farmers (friends) & 24 & 12.6 \\
Self-propagation & 18 & 9.5 \\
Private Hatcheries & 77 & 40.5 \\
Governmental departments & 68 & 35.8 \\
Type of Culture System & & \\
All-male & 127 & 66.8 \\
Mixed Sex & 49 & 25.8 \\
Polyculture & 12 & 6.3 \\
Mixed culture & 2 & 1.1 \\
Type of holding facilities & & \\
Earthen/Dugout Ponds & 108 & 56.8 \\
Concrete tank & 1 & 0.5 \\
Cages & 55 & 28.9 \\
Ponds and concrete tanks & 6 & 3.2 \\
Ponds and Cages & 14 & 7.4 \\
Ponds, concrete tanks and cages & 6 & 3.2 \\
\hline
\end{tabular}




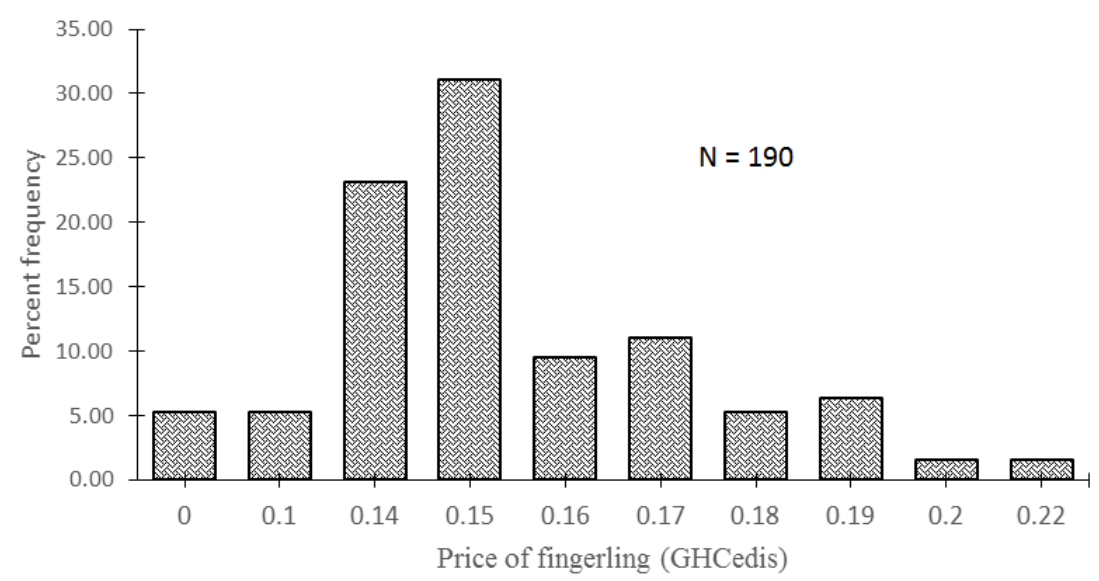

Figure 1. Price of $2 \mathrm{~g}$ fingerling sold at various farms along the southern sector of Ghana ( $1 \mathrm{USD}=4.3 \mathrm{GHC}$ )

Generally, respondents who were between the ages of 20-29 undertook more cage culture than the other age groups $(\mathrm{P}<0.05)$. However, respondent who were older than 30 years tended to undertake more pond culture only than the other types (Table 3). Persons who self-financed or had family support used more dugout ponds whilst those who took loans from banks undertook more cage culture $(\mathrm{P}<0.01)$. Furthermore, respondents who were in partnership as well as those who had spent more than 10 years in aquaculture had a significantly higher chance of using more than one production facility $(\mathrm{P}<0.01)$.

Table 3. Relationships between some parameters (age, family size and source of finance) on the type of culture facility used for aquaculture

\begin{tabular}{|c|c|c|c|c|c|c|c|c|c|}
\hline & $\mathrm{N}$ & $\begin{array}{l}\text { Concrete } \\
\text { tanks }\end{array}$ & Dugout & Cage & $\begin{array}{l}\text { Ponds } \\
\& \text { Cages }\end{array}$ & $\begin{array}{l}\text { Ponds \& } \\
\text { Tanks }\end{array}$ & $\begin{array}{l}\text { Ponds, } \\
\text { Tanks } \\
\text { Cages } \\
\end{array}$ & $\&$ & $\chi^{2}(p$-value $)$ \\
\hline \multicolumn{10}{|l|}{ Age } \\
\hline $20-29$ & 18 & 0.0 & 16.7 & 77.8 & 5.6 & 0.0 & 0.0 & & $46.79(0.00 *)$ \\
\hline $30-39$ & 35 & 2.9 & 48.8 & 40.0 & 8.6 & 0.0 & 0.0 & & \\
\hline $40-49$ & 69 & 0.0 & 66.7 & 23.2 & 4.3 & 2.9 & 2.9 & & \\
\hline $50-59$ & 53 & 0.0 & 68.6 & 17.6 & 5.9 & 3.9 & 3.9 & & \\
\hline$\geq 60$ & 15 & 0.0 & 46.7 & 13.3 & 26.7 & 6.7 & 6.7 & & \\
\hline \multicolumn{10}{|l|}{ Family size } \\
\hline No child & 19 & 5.3 & 31.6 & 52.6 & 10.5 & 0.0 & 0.0 & & \\
\hline $1-3$ & 76 & 0.0 & 69.7 & 19.7 & 2.6 & 2.6 & 5.3 & & $33.25(0.00 *)$ \\
\hline $4-6$ & 86 & 0.0 & 54.7 & 27.9 & 10.5 & 4.7 & 2.3 & & \\
\hline$\geq 7$ & 9 & 0.0 & 22.2 & 66.7 & 11.1 & 0.0 & 0.0 & & \\
\hline \multicolumn{10}{|c|}{ Source of Finance } \\
\hline Self & 112 & 0.00 & 56.25 & 33.93 & 6.25 & 1.79 & 1.79 & & \\
\hline Family support & 50 & 2.00 & 80.00 & 10.00 & 2.00 & 6.00 & 0.00 & & $99.49(0.00 *)$ \\
\hline Loan from bank & 17 & 0.00 & 29.41 & 52.94 & 17.65 & 0.00 & 0.00 & & \\
\hline Government & 2 & 0.00 & 0.00 & 0.00 & 0.00 & 50.00 & 50.00 & & \\
\hline Partnership & 9 & 0.00 & 0.00 & 33.33 & 33.33 & 0.00 & 33.33 & & \\
\hline \multicolumn{10}{|c|}{$\begin{array}{l}\text { Number of years } \\
\text { in aquaculture }\end{array}$} \\
\hline $1-3$ & 96 & 1.0 & 61.5 & 28.1 & 6.2 & 3.1 & 0.0 & & $37.46(0.00 *)$ \\
\hline $4-6$ & 70 & 0.0 & 58.6 & 31.4 & 2.9 & 1.4 & 5.7 & & \\
\hline 7-9 & 16 & 0.0 & 37.5 & 31.2 & 25.0 & 6.2 & 0.0 & & \\
\hline$\geq 10$ & 8 & 0.0 & 25.0 & 12.5 & 25.0 & 12.5 & 25.0 & & \\
\hline
\end{tabular}

The target market for majority of the farmers (93.2\%) were urban and peri-urban centres, however, point of sale of the products was at farm gate (85.3\%) in their fresh forms. The use of cold store facilities and market centres for sales of fish made up the remaining component (14.7\%). The respondents also noted that the customers preferred bigger fish (250g and above) over smaller fish (below 200g). High cost of feed and lack of financial 
assistance was noted by $73.2 \%$ and $51.9 \%$ of the respondents respectively to be a major challenge facing the industry.

\subsection{Perception of Farmers about Akosombo Strain}

There were 89 farmers who knew about the strain, of which fifty-two (52) used the strain for propagation. Farmers got information on the strain through friends $(70 \%)$ whilst the remaining gained information through workshops. Incidentally, majority $(55.8 \%)$ who used the strain responded that the price of a $2 \mathrm{~g}$ fingerling was moderate, whilst $40.4 \%$ thought the cost was either expensive or very expensive; and the remaining (3.8\%) felt the price was low. This notwithstanding majority of the farmers (63.5\%) attributed their choice for the fish to the proven performance (fast growth) whilst customer preference $(25.5 \%)$ was the next important factor. Consequently, most of the farmers gave a high score on the performance of the strain; ranking it as satisfactory $(48.1 \%)$ and highly satisfactory $(46.2 \%)$. Although there were other strains of tilapia been produced and sold to fish farmers, most of them were not well documented with respect to the parent material used to produce the strain. In some cases, hatcheries had purchased the Akosombo strain and had crossed them with broodstock from other farms or wild populations.

\subsection{Dissemination of Strains of Tilapia}

Dissemination of strains of Nile tilapia was undertaken by $32(16.8 \%)$ of the farmers; out of which 24 (75\%) farmers supplied fingerlings directly to other farmers, whereas the remaining $8(25 \%)$ sold both fingerlings and broodstock to other famers. A logistic regression analysis conducted to predict dissemination of tilapia by the farmers using age, level of education, family size, marital status, year in aquaculture, number of employees, source of fingerling, price of fingerling and type of holding facilities as predictors yielded a Nagelkerke's $\mathrm{R}^{2}$ of 0.389 indicating a moderately strong relationship (Table 4). A test of the full model against a constant only model was statistically significant, indicating that the predictors as a set reliably distinguished between disseminators and non-disseminators of tilapia (chi square $=45.715, \mathrm{p}<0.000$ with $\mathrm{df}=9$ ). Prediction success overall was $90.5 \%$ (97.6\% for non-dissemination and $46.2 \%$ for dissemination). The Wald criterion indicated that only price of $2 \mathrm{~g}$ fingerling made a significant contribution to prediction $(\mathrm{p}=0.001)$. The standardized beta coefficient, $\operatorname{Exp}(\beta)$, value indicates that when educational level is raised by one unit the odds ratio is 1.5 times as large and therefore farmers with higher education are 1.5 more times likely to disseminate tilapia.

Table 4. Some parameters and their effect on dissemination of tilapia

\begin{tabular}{lllllll}
\hline Predictors & B & S.E & Wald & Df & Sig. & $\operatorname{Exp}(\beta)$ \\
\hline Age & -0.123 & 0.270 & 0.209 & 1 & 0.647 & 0.884 \\
Marital Status & 0.208 & 0.934 & 0.049 & 1 & 0.824 & 1.231 \\
Level of education & 0.376 & 0.355 & 1.120 & 1 & 0.290 & 1.457 \\
Family size & -0.100 & 0.430 & 0.054 & 1 & 0.816 & 0.905 \\
Years in Aquaculture & -0.029 & 0.390 & 0.005 & 1 & 0.941 & 0.972 \\
Number of employees & 0.246 & 0.518 & 0.226 & 1 & 0.634 & 1.279 \\
Source of fingerling & 0.328 & 0.326 & 1.014 & 1 & 0.314 & 1.388 \\
Production facility & 0.234 & 0.226 & 1.067 & 1 & 0.302 & 1.263 \\
Price of fingerling & 0.036 & 0.010 & 11.781 & 1 & 0.001 & 1.036 \\
Constant & -5.526 & 2.296 & 5.795 & 1 & 0.016 & 0.004 \\
\hline
\end{tabular}

Reference $=$ No dissemination

\section{Discussion}

Culture of tilapia continues to be the major contributor to total aquaculture production in Ghana. The importance of this sector to food security, income generation and indirect benefits of employment cannot be over emphasized. The study revealed that men, who happen to the head of households, owned most $(98.4 \%)$ of the fish farms with majority of them being between the ages of 40-59. This may be due to the fact that most of the farms were run through self-financing (58.9\%) and family support (26.3\%). Although women are involved in the various aspects of aquaculture ranging from feed production to production of fish for market, ownership of aquaculture facilities have been dominated by males in most parts of the country. This situation is not peculiar to Ghana but cuts across most West-African countries (Trottier, 1987). Women usually get involved in the value chain by purchasing and processing fish for consumers. Raising farmers' income is a necessary precursor to high capital investment in agriculture. This can be achieved through reducing the sizes of families and hence dependency ratio. Increased involvement of women in decision-making framework will stimulate their 
participation in farming activities. Generally, few farms were run by full-time fish farmers $(25.8 \%)$ whilst $50 \%$ were run by farmers and persons involved in the informal business sector. This indicates that aquaculture is still seen as a part-time hobby, with minimal capital investment (Hiheglo, 2008; DoF, 2009). This further explains the low number of people that were employed on the farms (1-3); indicating that the farmers were mostly undertaking aquaculture on the subsistence level. However, farms who employed more than ten (10) people were mainly financed by partnership or the government. Although aquaculture is a profitable venture, low investment from the private sector as well as lack of information concerning economic profitability continue to mitigate against the growth of the sector. This is evidenced by the low numbers $(4.7 \%)$ of farmers who were funded through partnerships. However, with the rising cost of feed, fingerlings and the other inputs required for aquaculture, it may be necessary to consider other forms of financial assistance in enhancing productivity.

The dominating type of aquaculture undertaken is small scale with extensive production of all-male tilapia in earthen ponds. This situation is similar in other West African countries as well as East African countries (IFOAM, 2013). The type of breeding system employed reflected a range of different intended outcomes; either subsistence or commercial. Hiheglo (2008) noted that although aquaculture has great potential, the industry is dominated by small scale operators. These farmers purchase sex-reversed fingerlings and stock them in the facilities, however, most of the dug-out ponds operators were not feeding their fish on regular basis. Although the initial cost of setting up a dug pond may be lower than that of a cage, the high stocking density employed in the latter ensures that profits margins offset the initial cost. Antwi, Kuwornu, Onumah and Bhujel (in press) noted that the average production in cages was $74 \mathrm{~kg}$, however, productivity could be improved and increased to 1 ton per cage per cycle if the farms are managed properly. Cage culture is also threatened by theft and lack of well-designed market structure. Farmers also complained that their products are been purchased by customers at lower prices, reducing their profit margins. In addition, due to the high levels of productivity of cage, there is the need for access to preservation facilities. Thus choosing an aquaculture system is about managing a trade-off between available capital, skills and the quality of fish demanded by a farmer's potential market.

Culture practices undertaken by the farmers include purchase of all-males, mixed sex, polyculture and mixed farming. The moderate correlation between the levels of education and the culture practices undertaken on the farms $(r=0.22)$ indicates that most farmers (irrespective of the level of education) was more interested in purchasing sex-reversed fingerlings and growing them for the market than engaging in other complex practices. This also reflects the low level of technical knowledge of the farmers. Although mixed sex culture could be undertaken by farmers, they still preferred the use of sex-reversed males. However, a few farmers who practiced mixed sexed culture in the cages, generally use the facility for broodstock production. These were later transferred to dugout ponds from which egg and fry production were undertaken.

Although the sector has experienced a significant increase in production within the last decade, there are socio-economic factors which mitigate against its growth. Socio-economic factors such as level of education, income, occupation, farm size, land tenure, place of residence, culture and ethnicity, religion have been proposed to be major determinants of thought patterns, decisions and attitudes (Kodiwo, 2012). The distance to the hatchery was a factor which affected $39.5 \%$ of the respondents. This group indicated that distance to the hatchery increased mortality of fingerlings as well as added to the cost of production due to transportation. Stress and high mortality due to transportation of fish from one facility to another continues to be a challenge to fish farmers. The high rate of mortality (up to 50\%) that some farmers reported indicated the need for improvement in transportation of fish. This challenge as well as the high cost of fingerling and feed has been the paramount challenge for most farmers. Although most farmers obtained their supply of fingerlings from privately owned hatcheries and farms, those supplied by government agencies and departments were significantly cheaper $(p>0.05)$. However, farmers considered other factors such as personal relationship with the hatchery operator, proven performance of strain and advice from friends in deciding the choice of source of seed for production. Private hatchery operators most often provided means of transportation of fingerlings and broodstock. This may be an important factor in encouraging farmers to purchase fingerlings and broodstock from these hatcheries.

One challenge that most farmers faced was their inability to afford readily available feed. Most commercial fish feeds are either too expensive or unavailable to some farmers - especially, those in the Central Region. The resultant has been the frequent mixing of local feeds with kitchen wastes, whilst others feed sparsely. Fish feed is expensive in Ghana and is responsible for the high aquaculture production costs. They make up about 70 percent of the total production cost, with the imported feeds being 30 percent more expensive than the locally-produced ones (FAO, 2009, 2016). Whereas availability of fish seed (fingerlings) is not a major challenge in the industry, issues of the quality of the fingerlings has been a major concern to the farmers. As the seed is one of the most important components of the aquaculture development, availability of good quality seed whenever needed 
accelerates the industry growth. Therefore, in order to support the maximum potential growth of tilapia industry, policy makers, researchers and other involved should emphasize the seed production technology and its dissemination.

The dissemination of improved strains did not go through any properly laid down procedure. Farmers could purchase improved strains of broodstock and fingerlings directly from the nucleus i.e. ARDEC and other governmental agencies. Hatcheries crossed the Akosombo strain with any strain of their choice - either from the wild of from other farms. Hence the possibility of losing the genetic gains of the Akosombo strain cannot be overemphasized. Although Rosendal, Olesen and Tvedt (2012) raised concerns about possible challenges due to ownership of the Akosombo strain as well as potential conflicts over access and benefit sharing (ABS) and legal protection over tilapia genetic material, the survey revealed that some hatcheries developed their own strain after the purchase of the improved strain. This puts pressure on the research institution to produce enough to meet the demands of the market. Access to improved strains in the industry is very open with farmers been able to buy fingerlings and broodstock from most of the farms. A few well-established farms, however, were reluctant in selling fingerlings and broodstock to other farmers. In Ghana, accessing genetic resources is relatively uninhibited and thus faces several challenges (UNEP, 2008). Further to that, in Ghana, there is no specific legislation on ABS corresponding to the CBD provisions, the Bonn Guidelines or other international instruments. Country reports presented at the 2002 INGA Expert Consultation held in Thailand revealed that, in general, the capacity of the member country institutions (both public and private) to maintain and manage the improved strains is weak and overall strategies for the dissemination of these strains are lacking. This may be one of the reasons why some well-established farms were unwilling to share their improved strains to other farmers. Proper dissemination of improved strain will open key areas of collaboration that such as seed production, seed distribution, extension, financing for farm operations, and setting directions for the tilapia sector (ADB, 2005). Investment of capital into aquaculture has been a major concern for fish farmers in the country. Hence there is the need for education and sensitization of players/investors on the viability of aquaculture and the possible gains which can be made (Mbugua, 2007).

\section{Conclusion}

The study has brought some socio-economic factors which affects the choice of fish for aquaculture along the coastal districts of Ghana. The major challenges faced by fish farmers included: means of transportation of fingerlings, cost of feed and access to financial assistant; whiles indigenous knowledge of culture of tilapia, community patronage, theft and low price of farm products were minor factors. Few women own farms and this call for the sensitization and provision of support for women to venture into aquaculture. Most farmers use strains of tilapia other than the Akosombo strain and purchase their fingerlings from private hatcheries. Farmers who produced their own fingerlings used a combination of pond culture and either concrete tank or cage culture. However, pond culture remains the dominant holding facility used by farmers. The Akosombo strain of tilapia was used by $36.9 \%$ of the farmers, with a vast majority of the farmers $(70 \%)$ getting information on the strain through other farmers.

\section{Acknowledgement}

The researchers wish to express their sincere gratitude to the Regional University Forum for Capacity Building in Agriculture (RUFORUM) for providing funding the research. We also express our thanks to Mr. Kwabena Nkansah, Mr. Charles Adongo and Mr. Prosper Dordonu who assisted in the analyses of questionnaires.

\section{References}

Abban, E. K., Asmah, R., Awity, L., \& Ofori, J. K. (2009). Review on National policies and Programmes on Aquaculture in Ghana. SARNISSA.

Ansah, Y. B., Frimpong, E. A., \& Hallerman, E. M. (2014). Genetically-Improved Tilapia Strains in Africa: Potential Benefits and Negative Impacts. Sustainability, 6, 3697-3721. https://doi.org/10.3390/su6063697

Antwi, D. E., Kuwornu, J. K. M., Onumah, E. E., \& Bhujel, R. C. (in Press). Productivity and constraints analysis of commercial tilapia farms in Ghana. Kasetsart Journal of Social Sciences. https://doi.org/10.1016/j.kjss.2016.12.001

Aseidu, B., Failler, P., \& Beyens, Y. (2016). Enhancing aquaculture development: mapping the tilapia aquaculture value chain in Ghana. Reviews in Aquaculture, 8, 394-402. https://doi.org/10.1111/raq.12103

Asmah, R. (2013). Aquaculture site selection and carrying capacity estimates for inland and coastal aquaculture in West Africa. In L.G. Ross, T.C. Telfer, L. Falconer, D. Soto \& J. Aguilar-Manjarrez, eds. Site selection and carrying capacities for inland and coastal aquaculture, pp. 197-205. FAO/Institute of Aquaculture, 
University of Stirling, Expert Workshop, 6-8 December 2010. Stirling, the United Kingdom of Great Britain and Northern Ireland. FAO Fisheries and Aquaculture Proceedings No. 21. Rome, FAO. 282 pp.

Attipoe, F. Y. K. \& Abban, E. K. (2004). Evaluation of culture performance of ecotype collections of Nile tilapia (Oreochromis niloticus) from the Volta system as the basis for fish breeding and selection program in Ghana. In: Abban, E. K., Casal, C. M. V., Dugan, P., Falk, T. M.(Eds.), Biodiversity, Management and Utilization of West African Fishes. WorldFish Center Conference Proceedings, pp.16-17.

Attipoe, F. Y. K. (2006). Breeding and Selection for Faster Growth Strains of the Nile Tilapia, Oreochromis niloticus, in Ghana. (Doctoral Thesis, University of Cape Coast, Ghana),

Béné, C., \& Russell, A. J. M. (2007). Diagnostic study of the Volta Basin fisheries. Part 1 - Livelihoods and poverty analysis, current trends and projections. Volta Basin Focal Project Report No 7. WorldFish Center Regional Offices for Africa and West Asia, Cairo Egypt, and CPWF, Colombo, Sri Lanka, 67 p.

Bhujel, R. C. (undated). How to Produce Billions of High Quality Tilapia Fry. 8pp

Directorate of Fisheries (DOF). (2009). Annual Report for Fisheries Commission of the Ministry of Food and Agriculture. Ministry of Food and Agriculture, Ghana.

Eknath, A. E., \& Acosta, B. O. (1998). Genetic improvement of farmed tilapias (GIFT) project: Final report, March 1988 to December 1997. International Center for Living Aquatic Resources Management, Makati City, Philippines.

FAO (2009). Impact of rising feed ingredient prices on aquafeeds and aquaculture production. In: Rana, K.J.; Siriwardena, S.; Hasan, M.R. (ed). Fisheries and Aquaculture Technical Paper. No. 541. FAO, Rome, 63p.

FAO (2014). FAO Global Aquaculture Production Volume and Value Statistics Database Updated to 2012.

FAO (2016). Fishery and Aquaculture Country Profiles: The Republic of Ghana

Feder, G., Just, R. E., \& Zilberman, D. (1985). Adoption of Agricultural Innovations in Developing Countries: A Survey. Economic Development and Cultural Change, 33(2): 255-298. https://doi.org/10.1086/451461

Ghana News Agency, GNA (2017). Ghana's annual fish production deficit over 600,000 metric tonnes. https://www.ghanabusinessnews.com/2017/02/11/ghanas-annual-fish-production-deficit-over-600000-metri c-tonnes/ view February 13, 2107.

GIFT (1998). Genetic Improvement of Farmed Tilapia (GIFT) Project. Final Report. March 1988 to December 1997) Part 1. ICLARM. Makati, Metro Manila.

Gjoen, H. GIFT Program Continues: Distribution of Fast-Growing Tilapia to Expand. Available online: http://pdf.gaalliance.org/pdf/GAA-Gj\%F8en-Dec01.pdf (accessed on 11 $1^{\text {th }}$ November 2016).

Government of Ghana (2017). Ministry Of Fisheries And Aquaculture Development. http://www.ghana.gov.gh/index.php/media-center/news/2234-ministry-of-fisheries-and-aquaculture-develop ment. viewed February 12, 2017

Hiheglo, P. K. (2008). Aquaculture In Ghana; Prospects, Challenges, Antidotes And Future Perspectives. (Master Thesis, University of Troms $\emptyset$, Norway).

IDAF (1993). Terminal report, IDAF project, Yeji, Ghana, 196.

IFOAM (2013). Scoping Study on Organic Aquaculture in 5 East African Countries. Censkowsky, U. \& Altena, A. (eds). International Federation of Organic Agriculture Movement, 64pp.

Jenkins, A., Velandia, M., Lambert, D. M., Roberts, R. K., Larson, J. A., English, B. C., \& Martin, S. W. (2011). Factors Influencing the Selection of Precision Farming Information Sources by Cotton Producers. Agricultural and Resource Economics Review, 40(2), 307-320. https://doi.org/10.1017/S106828050000808X

Kodiwo, M. P. (2012). Social-economic factors influencing agricultural land use intensity in Siaya district Kenya. (Master's thesis. Kenyatta University, Kenya)

Lind, C. E., Safari, A., Agyakwah, S. K., Attipoe, F. Y. K., El-Naggar, G. O., Hamzahd, A., ... Ponzoni, R.W. (2015). Differences in sexual size dimorphism among farmed tilapia species and strains undergoing genetic improvement for body weight. Aquaculture Reports 1, 20-27. https://doi.org/10.1016/j.aqrep.2015.03.003

Little, D. C., Murray, F. J., Leschen, W., \& Waley, D. (2013). Socio-economic factors affecting aquaculture site selection and carrying capacity. In L.G. Ross, T.C. Telfer, L. Falconer, D. Soto \& J. Aguilar-Manjarrez, eds. 
Site selection and carrying capacities for inland and coastal aquaculture, pp. 103-115. FAO/Institute of Aquaculture, University of Stirling, Expert Workshop, 6-8 December 2010. Stirling, the United Kingdom of Great Britain and Northern Ireland. FAO Fisheries and Aquaculture Proceedings No. 21. Rome, FAO. 282 pp.

Mittal, S. (2012). Modern ICT for Agricultural Development and Risk Management in Smallholder Agriculture in India. CIMMYT. Socio-Economics Working Paper 3. Mexico: CIMMYT

Mittal, S., \& Mehar, M. (2016). Socio-economic Factors Affecting Adoption of Modern Information and Communication Technology by Farmers in India: Analysis Using Multivariate Probit Model, The Journal of Agricultural Education and Extension, 22(2), 199-212. https://doi.org/10.1080/1389224X.2014.997255

MOFAD (2013). 2012 Annual report. Accra, Ghana: Ministry of Fisheries and Aquaculture Development.

MOFAD (2014). 2013 Annual report. Ministry of Fisheries and Aquaculture Development

Moreira, R. (2002). Contribution of omnivorous tilapia to eutrophication of a shallow tropical reservoir: Evidence from a fish kill. Freshwater Biology, 47, 2443-2452. https://doi.org/10.1046/j.1365-2427.2002.01013.x

Nunoo, F. K. E., Asamoah, E. K., \& Osei-Asare, Y. B. (2014). Economics of aquaculture production: a case study of pond and pen culture in southern Ghana. Aquaculture Research, 45(4), 675-688. https://doi.org/10.1111/are.12003

Ofuoku, A. U., Emah, G. N., \& Itedjere, B. E. (2008). Information Utilization among Rural Fish Farmers in Central Agricultural Zone of Delta State, Nigeria. World Journal of Agricultural Sciences, 4(5), 558-564.

Otieno, O. N., Kitaka, N., \& Njiru, J. M. (2014). Some aspects of the feeding ecology of Nile tilapia, Oreochromis niloticus in Lake Naivasha, Kenya. International Journal of Fisheries and Aquatic Studies, 22, 01-08.

Ponzoni, R. W. (2006). Genetic improvement and effective dissemination: Keys to prosperous and sustainable aquaculture industries. In: R. W. Ponzoni, B. O. Acosta and A. G. Ponniah (eds), "Development of Aquatic Animal genetic Improvement and Dissemination Programs: Current status and action plans". WorldFish Center Conference Proceedings 73, 120p.

Ponzoni, R. W., Nguyen, N. H., Khaw, H. L., \& Rodriguez Jr. B. M. (2012). Considerations about effective dissemination of improved fish strains. WorldFish, Penang, Malaysia. Working Paper: 2012-47.

Rosendal, G. K., Olesen, I., \& Tvedt, M. W. (2012). Access to, equity and protection of genetic resources in Ghana: The case of tilapia (O. niloticus). FNI Report 15/2012, 28pp.

Simpson, G. (2012). Opportunities for Small Scale Suppliers within the Tilapia Value Chain in Ghana: a case study of fish farming in Achavanya. (Master's thesis.,The Hague, The Netherlands)

Thompson, N. M. (2012). Two Studies Evaluating Input Use in Soybean and Cotton Production. (Master's Thesis, University of Tennessee). Available at http://trace.tennessee.edu/utk_gradthes/1215

Trottier B, (1987) Women in Aquaculture Production in West Africa. In: FAO Corporate Document Repository. Women in Aquaculture. Originated by Fisheries Aquaculture Department. Rome, Itali. [Online] Available at: www.fao.org/docrep/s4863e05.htm- (Accessed: 2/18/2017).

UNEP (2008). Access to Genetic Resources in Africa: Analysing ABS Policy Development in Four African Countries, pp 25-34.

Wijkstrom, U. N., \& MacPherson, N. J. (1990). A cost benefit analysis of culture based fisheries development in small dams and dugouts. Field work paper 1: the economics of culture based fisheries. Field Document F1:TCP/GHA0051. FAO, Rome, Italy.

Woynarovich, E. (1979). The feasibility of combining animal husbandry with fish farming, with special reference to duck and pig production. Pp 203-208. In: T. V. R. Pillay and Wm. A. Dill (eds), Advances in Aquaculture. 653pp.

\section{Copyrights}

Copyright for this article is retained by the author(s), with first publication rights granted to the journal.

This is an open-access article distributed under the terms and conditions of the Creative Commons Attribution license (http://creativecommons.org/licenses/by/3.0/). 